\title{
Silicification and dolomitization of anhydrite nodules in argillaceous terrestrial deposits: an example of meteoric-dominated diagenesis from the Triassic of central Spain
}

\author{
A. M. ALONSO-ZARZA, Y. SÁNCHEZ-MOYA, M. A. BUSTILL@ A. SOPEÑA \\ and A. DELGADO
}

\begin{abstract}
Cauliflower-shaped nodules are widespread in a single red mudstone bed in the Buntsandstein (Triassic) facies of the Iberian Range. They consist mostly of quartz, dolomite and calcite, but other minerals, such as barite, kaolinite and iron oxyhydroxides, are also present. The nodules are spherical, ovoid or elongate in shape and range from 1 to $8 \mathrm{~cm}$ across. The surface of the nodules is irregular, and some show a pedogenic coating of microspar. The sedimentological and petrographic data suggest that the initial anhydrite nodules formed through a progressive increase in the porewater concentration of $\mathrm{Ca}^{2+}$ and $\mathrm{SO}_{4}{ }^{2-}$ in a vadose environment, occasionally under the influence of pedogenic processes. Partial replacement of the anhydrite by megaquartz occurred under more dilute conditions in the same type of setting, as indicated by the presence of organic filaments on the quartz crystal surfaces. In type $\mathrm{A}$ nodules, the dissolution of the innermost anhydrite was complete, and different types of quartz cement filled the porosity. Fracturing and meteoric cementation by calcite and minor amounts of kaolinite were the latest processes affecting these nodules. In type B nodules, the dissolution of the anhydrite was incomplete, inhibiting quartz cementation and enabling later dolomitization of the anhydrite. Dolomitization appears to have been driven by sulphate reduction, as indicated by the presence of bacterial bodies within the dolomite crystals. Dedolomitization and precipitation of barite, kaolinite and calcite spar cements occurred later under the influence of meteoric solutions. The nodules may mark the former locations of the water table and provide evidence for an episode of highly evaporitic conditions throughout wide areas of the basin. Their occurrence reveals not only a complex diagenetic history but is also indicative of palaeogeographic and palaeoclimatic conditions.
\end{abstract}

Keywords Anhydrite nodules, meteoric diagenesis, silicification, Spain, sulphate-reduction dolomitization, Triassic. 


\section{INTRODUCTION}

The replacement of anhydrite nodules by quartz and carbonates (very often dolomite) has been recognized in sedimentary rocks from the Precambrian to the Tertiary. These nodules have often been termed 'cauliflower nodules' because of their shape and colour. They are more common in marine than in terrestrial depositional environments. In the former, they appear in settings interpreted to be sabkhas (Chowns \& Elkins, 1974), intertidal to shallow subtidal (Geeslin \& Chafetz, 1982) and even in deeper subtidal overlain with evaporitic supratidal sediments (Elorza \& Rodríguez-Lázaro, 1984; Maliva, 1987). In most cases, silicification and dolomitization are closely associated processes that occurred during early diagenesis. In terrestrial environments, these nodules have only been reported in playa-lake deposits (Tucker, 1976a).

Cauliflower nodules may serve as indicators of ancient shorelines (Chowns \& Elkins, 1974), emersion surfaces (Gómez-Alday et al., 1994), palaeoclimate (Tucker, 1976a; Elorza \& Rodríguez-Lázaro, 1984) and as an evidence for hypersaline porewaters during early diagenesis (Maliva, 1987). The cauliflower nodules of the Triassic of the Iberian Range are of interest for several reasons. The Iberian Range nodules are restricted to a single, widespread bed of red mudstones within the Buntsandstein facies of the Iberian Range, so their formation was therefore under lithological and sedimentological control. The nodules occur in terrestrial deposits, associated with biogenic features, in which environment cauliflower nodules have rarely been described. The Iberian Range nodules also have a more complex mineralogy and structure than those commonly described in other cauliflowerlike nodules.

The aim of this investigation was to decipher the sequence of sedimentary and diagenetic processes responsible for the formation of these nodules. Of particular interest was information that the cauliflower nodules might provide on palaeoclimate, tectonic regimes and the composition and levels of ancient groundwater.

\section{STRATIGRAPHICAL AND SEDIMENTOLOGIC SETTING}

The Triassic Basin of central Iberia was an extensional basin controlled by the movements of two main fault systems running NW-SE and
SW-NE (Fig. 1). These fault systems formed during the last stages of the Hercynian movements. In the study area, the reconstruction of the Triassic Basin reveals two different domains: a north-eastern one, where the thickness of the Triassic deposits reaches $950 \mathrm{~m}$; and a southwestern one, in which maximum thickness is $200 \mathrm{~m}$ (Fig. 1, A-B section). These domains are separated by an important basal detachment, the movements of which were contemporary with sedimentation and were responsible for the variation in thickness along the basin. Back-faulting and widespread extensional processes, acting in the basin around the transition from the lower to the middle Triassic, led to an increase in the sedimentation area towards the west and southwest (Sopeña et al., 1988).

The Triassic sedimentary record is composed of three lithologicaly distinctive stratigraphic successions (Fig. 1). The lower succession consists of red beds of fluvial origin (Buntsandstein) that rest unconformably on Hercynian or Permian basement. The intermediate succession consists of carbonates with intercalated detrital beds (Muschelkalk) that were deposited in shallow-marine environments. The upper succession (Keuper) is composed of evaporites, such as laminated and nodular gypsum and anhydrite, interbedded with detrital sediments. Intertidal carbonates of the Dolomías Tableadas de Imón Formation overlie the Keuper deposits. The total thickness of Mesozoic deposits overlying the Buntsandstein facies in the study area varies from 400 to $700 \mathrm{~m}$.

The cauliflower nodules occur within Buntsandstein red beds. These facies consist of four fluvial units, designated C, Ss, S and Sm (Fig. 1), that were deposited in braided and meandering stream environments (Sopeña \& Sánchez-Moya, 1997). The cauliflower nodules are located in the uppermost unit $(\mathrm{Sm})$, which varies in thickness from $30 \mathrm{~m}$ in the W. Pálmaces section (Fig. 1, no. 2) to $10 \mathrm{~m}$ in the Cardeñosa section (Fig. 1, no. 8). The unit consists of massive mudstones and interbedded sandstones. The geometry of the sandstone beds varies from: (a) tabular beds with planar, slightly erosive bases and concave margins and internal fining-upwards sequences bounded by epsilon-like surfaces, corresponding to high-sinuosity channels within a meandering fluvial system; (b) thin, wide tabular beds showing parallel lamination and current ripples, corresponding to crevasse-splay deposits; and (c) bodies with planar bases and convex tops a few metres wide that correspond to levees of the channel margin. Unit Sm was deposited in a very 


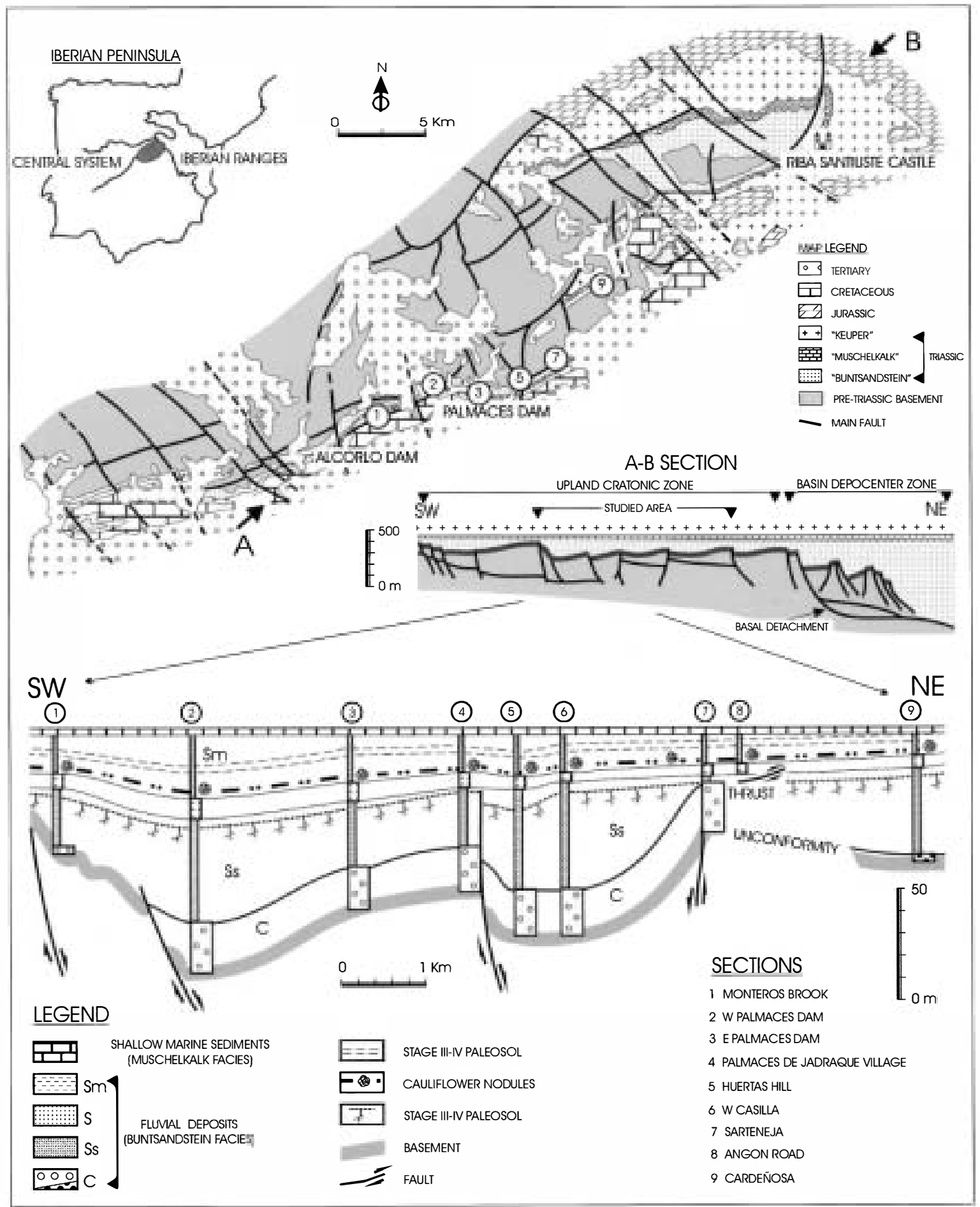

Fig. 1. Geological map, stratigraphy and main tectonic elements active during the Triassic sedimentation of the study area. The lower sketch shows simplified stratigraphic sections and the main stratigraphic units of the study area. The cauliflower-shaped nodules occur in a red mudstone bed in the Sm unit and are widespread throughout the area.

low-lying distal area with very narrow channels (ribbons) that occasionally meandered.

The transition to marine carbonates and terrigenous sediments (Muschelkalk) is relatively fast and is shown by 1-2 $\mathrm{m}$ of fining-upwards sequ- ences at the topmost part of the unit. These sequences consist of mudstones and fine-grained sandstones with tidal lamination, occasional halite pseudomorphs and fine carbonate levels with 'tepee' structures. Similar facies and 
sequence associations have been reported elsewhere in transitional environments (Diemer \& Bridge, 1988; Muñoz et al., 1992).

\section{METHODS}

The studied exposures of the cauliflower nodules were documented in previous investigations performed in the study area by Sopeña et al. (1995), Sánchez-Moya et al. (1997) and others. The nodules examined in the present study came from nine localities (Fig. 1). More than 100 nodules were cut in order to obtain polished hand specimens. Thin sections of 35 nodules were studied under transmitted light and cathodoluminescence (CL). Sample mineralogy was determined using a Philips XR system operating at $40 \mathrm{kV}$ and $30 \mathrm{~mA}$ with monochromated $C u K_{a}$ radiation. Scanning electron microscopy (SEM) was performed with a JEOL 6.400 working at $20 \mathrm{kV}$; fracture surfaces were covered with gold, whereas polished surfaces were carbon-coated for back-scattered analyses. Microprobe analyses were performed with an EPMA using WDS, model JXA 900 (Jeol) from UCM. The standards used are described by Jarosewich et al. (1980) and were provided by the Smithsonian Institute, Washington, USA. Microprobe analyses concentrated on determining the proportions of the major element compositions within the different phases.

Isotope measurements were performed at the Stable Isotope Laboratory of the Estacion Experimental del Zaidín (CSIC, Granada, Spain). Samples were ground to $<200$ mesh and treated with $100 \%$ phosphoric acid for $12 \mathrm{~h}$ in a thermostatic bath at $25^{\circ} \mathrm{C}$ (McCrea, 1950). In samples containing calcite and dolomite, a double extraction at $25^{\circ} \mathrm{C}$ and $50^{\circ} \mathrm{C}$ was performed (Al-Aasm et al., 1990). Acid fractionation factors used were 101044 at $25^{\circ} \mathrm{C}$ for calcite (Kim \& O'Neil, 1997) and 1.01065 at $50^{\circ} \mathrm{C}$ for dolomite (Rosenbaum \& Sheppard, 1986). Isotopic ratios were measured by a Finnigan MAT 251 mass spectrometer. The experimental error for carbonates $\left(\delta^{13} \mathrm{C}\right.$ and $\left.\delta^{18} 0\right)$ was $\pm 1 \%$, using Carrara and EEZ-1 as internal standards previously calibrated to NBS-18 and NBS-19.

\section{OCCURRENCE OF THE CAULIFLOWER- LIKE NOUULES}

As mentioned above, the cauliflower nodules occur scattered in the lowermost part of unit Sm
(Fig. 1). The bed containing the nodules extends for more than $30 \mathrm{~km}$. Within the red mudstone bed, the nodules show a general horizontal trend. The mudstone bed consists of illite within a microcrystalline mosaic of dolomite crystals and includes variable amounts of etched detrital grains, such as quartz and feldspars. The mudstone bed was deposited in the floodplain of a meandering river system.

\section{PETROLOGY}

The nodules are spherical, ovoid or, in some cases, elongate. They range from 1 to $\mathrm{cm}$ across. Their surfaces are irregular and have a 'cauliflower' shape (Fig. 2). Some nodules are composed of several smaller nodules separated by films of red to green clays cemented by dolomite. The outer surface of the nodules is red or, less conmonly, green. Some nodules show a discontinuous cortex of several millimetes of laminated micropseudospar calcite.

Many of the nodules show a concentric structure defined by a succession of different types of quartz and carbonate phases (Fig. $3 \mathrm{~A}$ and B). Other nodules lack the concentric structure because a network of fractures resulted in the brecciation of the nodule. The nodules are composed of quartz $(30-100 \%)$, calcite $(5-70 \%)$, dolomite $(-35 \%)$, anhydrite $(-5 \%)$, barite $(\bullet-5 \%)$, kaolinite $(-5 \%)$ and goethite $(\bullet-5 \%)$.

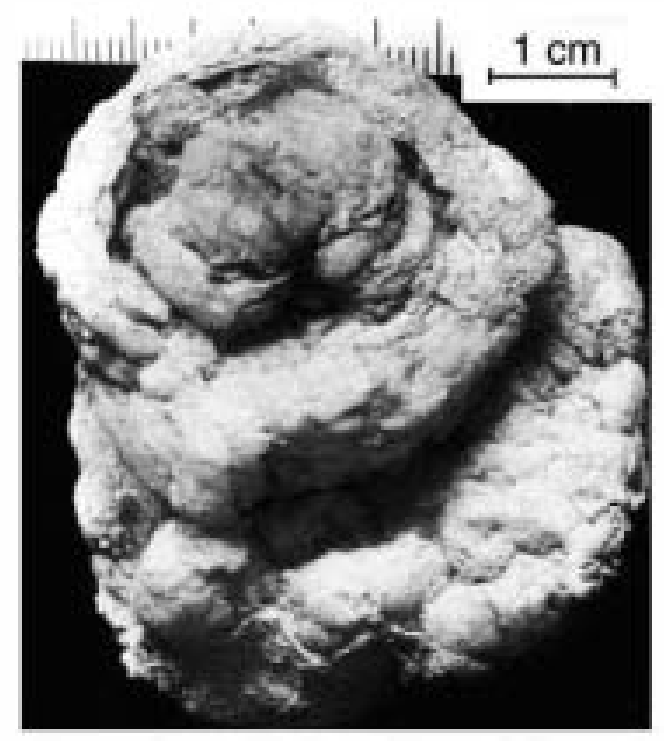

Fig. 2. External morphøløgy of a caulifløwer-shaped nodule. 

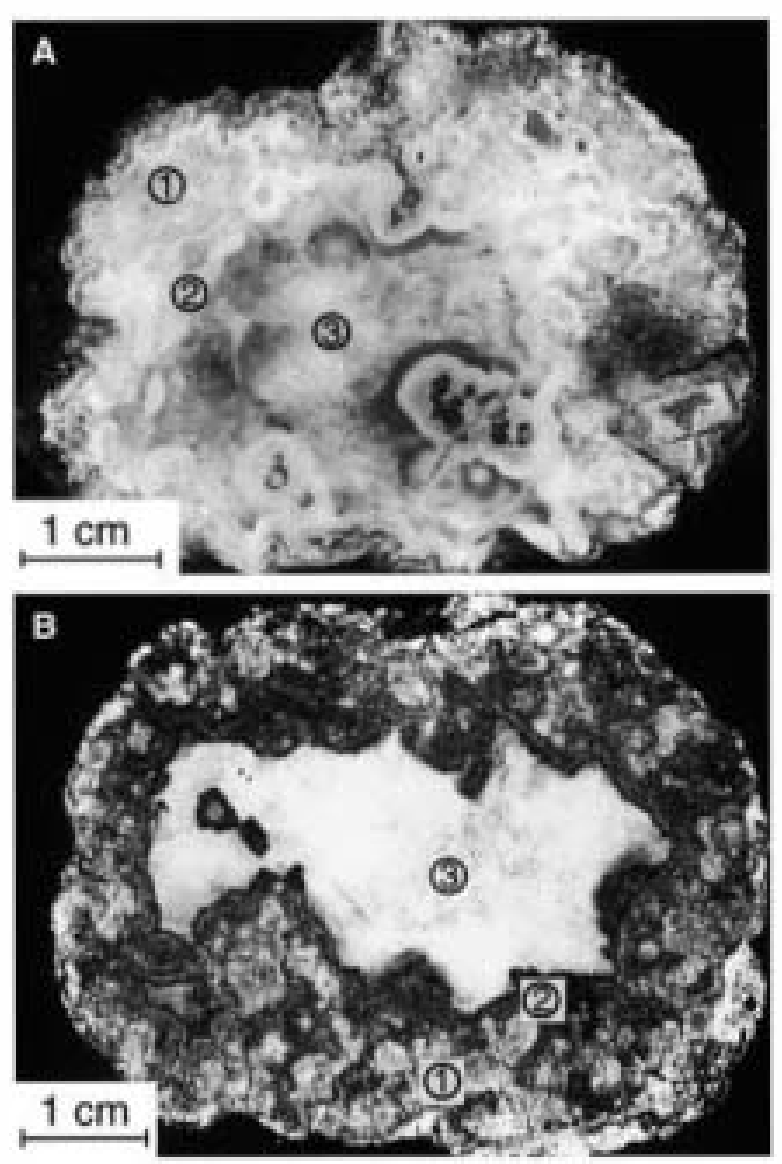

Fig. 3. Polished hand samples of the cauliflewer nedules. (A) Type A rodule showing: 1, megaquartz; 2 , quartzire and flbrous quartz; 3 , calcite cement. (B) Type B rodule showirg: 1, megaquartz; 2, zөned delomite; 3, calcite cement.

\section{Petrography}

\section{The outer carbonate cortex}

Some quartz nodules show a discontinuous crutex of microspar several millimetres thick. The microspar laminae consist of calcite crystals (40 $\mu \mathrm{m}$ across). The laminae have spheroidal to ovoid pores (Fig. 4A) of $<1 \mathrm{~mm}$ across and ghosts of micritic filaments. This cortex also includes etched detrital quartz and feldspar grains as well as clays.

\section{Quartz fabrics and testures}

Quartz forms the outermost part of the nodules (Fig. 4b-E) and, in a fow cases, the whole nodule. Quartz shows two textures: megaquartz and length-slow chalcedony (quartzine), both of which may occur as fragments within nodules (Fig. 4F). In nodules containing both textures, megaquartz occupies the outermost part, whereas quartzine is located towards the interior (Figs 4 and $5 \mathrm{~A}$ ). Megaquartz, which is the most abundant quartz phase, occurs as single euhedral crystals and inequigranular mosaics of clusters of crystals in a carbonate matrix as well as in bands of elongated crystals.

The inequigranular mosaics consist of subhedralto euhedral crystals (Fig, 4B) that vary in size Exm $0 . \bullet 3$ to $3 \mathrm{~mm}$ across. The crystals display unit or undulose extinction (tlamboyant and microflamboyant quartz). These features are typical of the megaquartz formed by replacement of sulphates (Milliken, 1979; Arbey, 1980). Anhydrite inclusions ane only seen in the megaquartz writh homogeneous extinction, and they are commonly disordered within crystals. Inclusions tend to be more prevalent along the external parts of the nodules.

The single and clusters of euhedral crystals (Fig. 4A) are mainly hexagonal bipyramidal and up to $4 \mathrm{~mm}$ long (Fig. 5B). The quartz crystals conmonly contain anhydrite inclusions that are either: (a) organized as bands parallel to the crystal faces (Fig. 5B); (b) concentrated in the central part of the crystals (Fig. 5C); or (c) disorganized and scattered throughout the crystals. The quartz crystals are isolated within mosaics of calcite or dolomite in the most central part of the nodules (Fig. 5D).

Under SEM, the extemal surface of the quartz crystals exhibits very regular and flat surfaces to irregular surfaces enclosing relics of anhydrite (Fig. 5E) and incipient corrosion by carbonates. The regular surfaces can include large organic flaments hundred of microns long and about $2 \mu \mathrm{m}$ across (Fig. 5E and F). In some samples, the relatively regular and flat surfaces have circular structures about $70 \mathrm{fm}$ in diameter (Fig. 5G and H) that are probably produced by dissolution of a fibrous rim of quartzine that enveloped the external area or the euhedral quartz crystals. Spherical to ovoid bodies of dolomite, about $1 \mathrm{~lm}$ in diameter, probably bacterial in origin, are present on the megaquartz surfaces (Fig. 6A).

Elongated (acicular, palisadic or columnar) megaquartz crystals form thin bands in the inner part of the nodule (Fig. (B). The crystals are about $0.2 \mathrm{~mm}$ long, $30 \mu \mathrm{m}$ in width and are perpendicular to the surfaces on which they lie. The crystals and their arrangement clearly resemble drusy cements.

Quartzine is less conmon than megaquartz and is only seen in nodules with a relatively thick ring of quartz. Quartzine commonly occurs as 
the described textures appear as fragments cemented by calcite (Fig. 4F), overall forming a breccia.

\section{Carbonate fabrics and textures}

Dolomite occurs as bands in the inner part of the nodules (Figs 3B and 4B) and as mosaics of euhedral dolomite crystals up to $4 \mathrm{~mm}$ in length, which may include euhedral quartz (Fig. 5D). The quartz-dolomite contact is sharp, and signs of corrosion of quartz by dolomite, such as dissolution embayments within the quartz, are uncommon. Under CL, dolomite is orange and commonly luminesces brightly. Dolomite is ferroan $\left(\mathrm{Ca}_{491^{-}}\right.$ $\mathrm{Mg}_{47} \mathrm{Fe}_{3.5} \mathrm{CO}_{3}$ ) and, locally, a richer iron phase similar to ankerite $\left(\mathrm{Ca}_{63} \mathrm{Mg}_{3} \mathrm{Fe}_{34} \mathrm{CO}_{3}\right)$ was detected by the microprobe. In most cases, the dolomite has undergone dedolomitization, which appears to have concentrated iron/manganese on some crystal faces and produced some crystals showing alternate calcite and dolomite zones (Fig. 6C). Dolomite and calcite after dolomite are absent in nodules that contain rims of quartzine.

Inclusions of anhydrite occur in the dolomite mosaics. In some cases, the inclusions were leached, and only their moulds are preserved, either empty or filled by calcite. Under SEM, the dolomite crystals show textures indicating partial dissolution and, in some cases, dedolomitization. Some organic structures, such as spherical bodies of about $1 \mu \mathrm{m}$ in diameter (bacteria), as well as large filaments, occur within the dolomite crystals (Fig. 6D).

Calcite occurs as a replacement of dolomite or as cement. The mean composition of calcite cements is $\mathrm{Ca}_{99 \cdot 1} \mathrm{Mg}_{\cdot 71} \mathrm{Fe}_{2} \mathrm{CO}_{3}$, whereas calcite that replaced dolomite is enriched in $\mathrm{Mg}$ and $\mathrm{Fe}\left(\mathrm{Ca}_{95-99} \mathrm{Mg}_{3 \cdot 5-1 \cdot 5} \mathrm{Fe}_{1-15} \mathrm{CO}_{3}\right)$. Calcite formed through replacement of dolomite occurs as euhedral mosaics that include the quartz crystals. The calcite crystals have some bands enriched in goethite and have a high intracrystalline porosity. Evidence of a dolomitic precursor includes: the rhombic morphology of the crystals and the preservation of dolomite within some zones of the crystals. Calcite cements are composed of euhedral to subeuhedral limpid calcite crystals, which vary in size from $10 \mu \mathrm{m}$ to $5 \mathrm{~mm}$, increasing towards the centre of the nodule. These calcite cements occur: (a) in the innermost part of the nodules, filling the central void (Figs $3 \mathrm{~A}, \mathrm{~B}$ and $4 \mathrm{E}$ ); (b) in fracture porosity (Fig. 4F); and (c) filling the moldic porosity left by the dissolution of anhydrite inclusions within quartz and dolomite crystals. CL images have shown that these mosaics have bright orange luminescence and dark zones.

\section{Sulphates}

Anhydrite (about $100 \mu \mathrm{m}$ across) is only present as inclusions within the megaquartz and dolomite. In the dolomite mosaics, inclusions are sparse and show no preferred distribution. The distribution pattern of the inclusions within the quartz mosaics and euhedral crystals was described above.

Barite occurs as lenticular to tabular crystals up to $5 \mathrm{~mm}$ long (Fig. 6E). These crystals may be isolated or connected to each other forming incipient 'desert roses' within calcite. Barite occurs only in nodules that originally contained dolomite. Barite shows signs of corrosion and is encased by optically continuous calcite, and hence predates calcite.

\section{Kaolinite}

Kaolinite was identified based on chemical composition $\left(40.3 \% \mathrm{SiO}_{2}\right.$ and $\left.36.57 \% \mathrm{Al}_{2} \mathbf{O}_{3}\right)$ and $\mathrm{X}$-ray diffraction (XRD) patterns. The crystals are about $30 \mu \mathrm{m}$ long, and form fans of $\approx 0.4 \mathrm{~mm}$ in diameter (Fig. 6E). They are present near the contact between the last silica phase and the carbonate phases, and either in fractures through the siliceous part of the nodules or in the innermost part of the nodules (Fig. 4E).

\section{Goethite}

Much of the goethite occurs as thin bands parallel to the faces of the carbonate crystals. Goethite occurs as $3-\mu \mathrm{m}$-diameter crystals with a flower- or spherulite-like texture. In nodules containing a large inner zone of dolomite, square morphologies suggestive of oxidized pyrites are present locally. Goethite also occurs along the external boundary of the quartzine rims or at the contact between silica or carbonate phases and the late calcite cement. Bustillo et al. (1999) described large haematite crystals in quartz nodules of similar age. These were not seen in the present study area.

\section{Host rock relics}

Relics of red mudstone are present within the nodules, mostly at the contact between the siliceous and carbonate phases. These preserved relics of the host rock contain some biogenic 


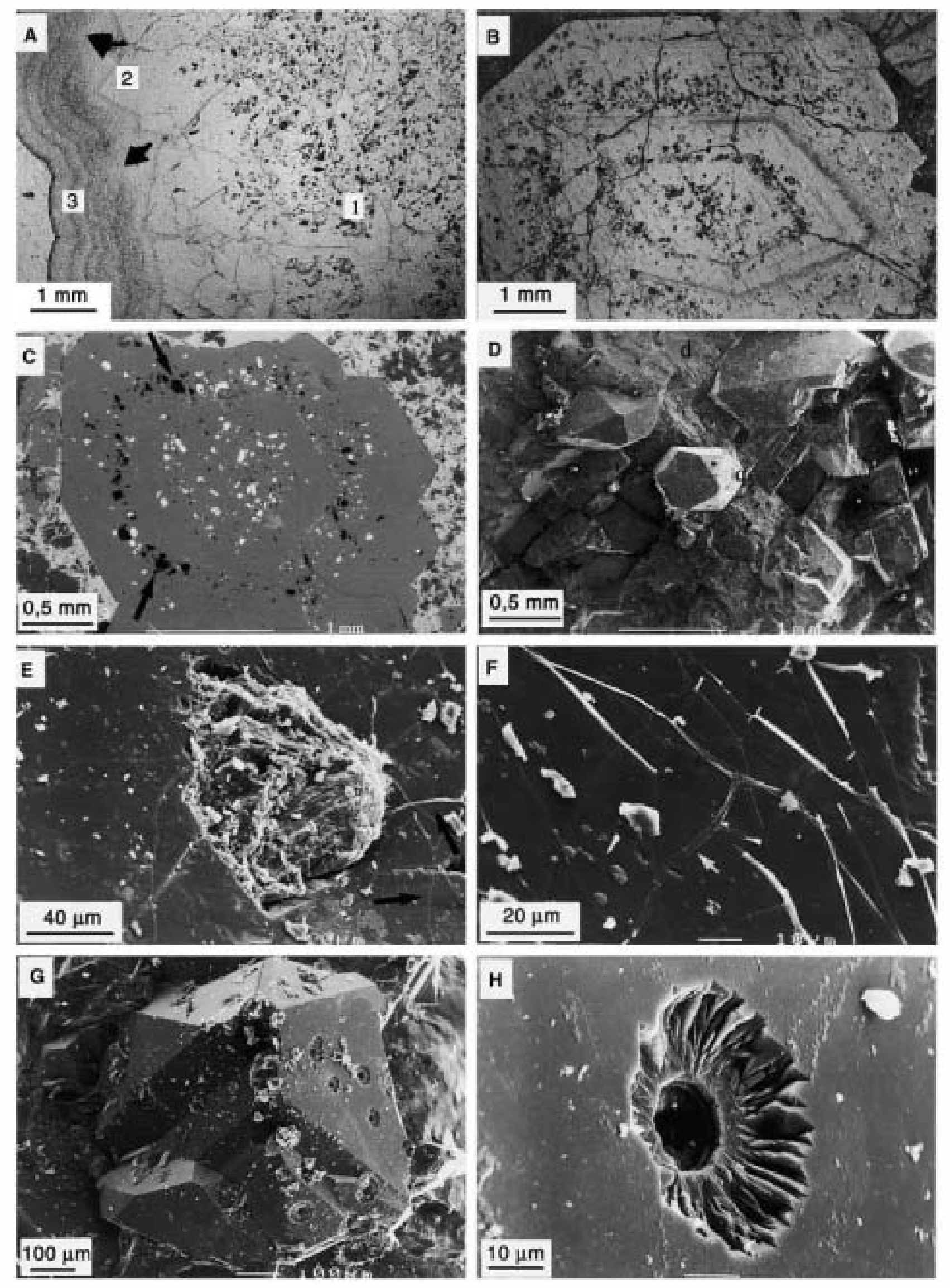


Fig. 5. (A) Arrangement of different quartz phases within a nedule, from the exterierte the interier: megaquartz with

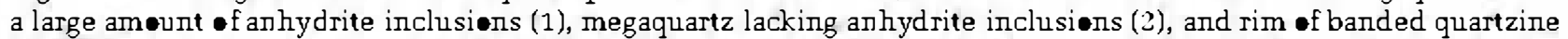
(3). (B) Euhedral quartz shewing different phases of grewth indicated by the erganized inclusi $\bullet$ ns $\bullet$ anhydrite. (C) Back-scattered image ef a megaquartz crystal revealing a hemegene cus cempesitien, even when the anhydrite bands suggest different growth phases. Anhydrite inclusiens are cencentrated in the centre ofthe crystal and in a band

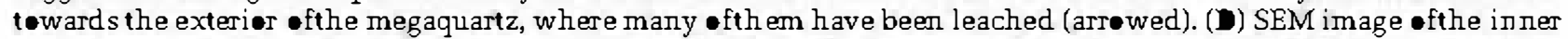

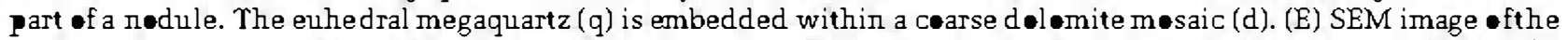
surface of a megaquartz crystal with an inclusien of partially disselved anhydrite and seme erganic fungal (?) filaments (arr wed). (F) SEM image of the surface ef a megaquartz crystal ceated by a number ef erganic filaments. (G)

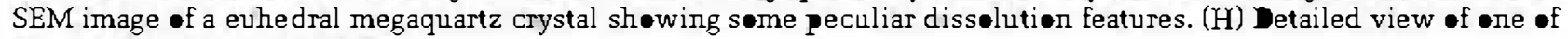
the selution features of $(G)$.
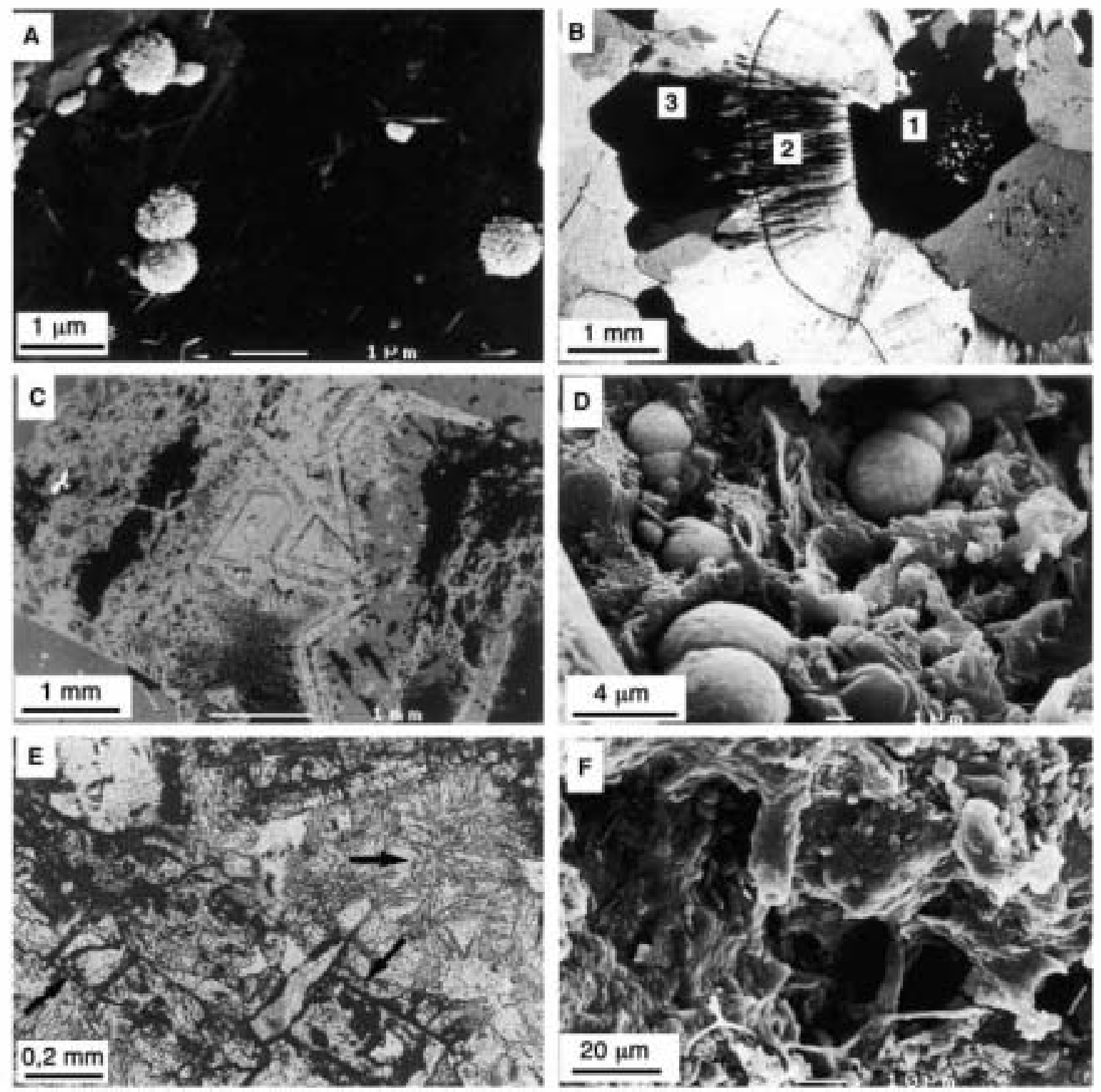

Fig. *. (A) SEM image of seme spherical bedies (bacteria) en the surface of a megaquartz crystal. (B) Ph $\bullet$ graph $\bullet f$ a sequence $\bullet$ : megaquartz (1), quartzine (2) and palisadic quartz (3) (detailed view of Fig. $4 \mathbf{D}$ under cress nichels). (C) Back-scattered image of cempesiti $\bullet$ nal zening within dedelemitized areas; darker bands cerrespend te

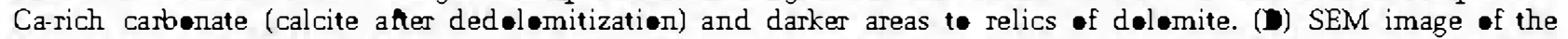

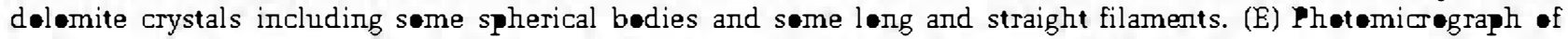
barite crystals (arrews) and kaelinite tewards the upper right angle (alse arrewed). Kaelinite crystals are arranged in

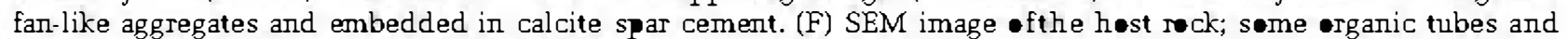
filaments are still preserved within the delemitic red mudstenes. 
structures, probably fungal filaments, which have not collapsed (Fig. 6F). Some etched detrital grains such as quartz and feldspars are also present.

\section{ISOTOPE GEOCHEMISTRY}

Stable isotope analyses were carried out on the calcite and dolomite of the nodules. Seventeen samples were analysed, all of them containing calcite, and five containing dolomite as well (Fig. 7). In calcites, either cement or replacing dolomite, $\delta^{13} \mathrm{C}$ values vary between $-9 \cdot 2 \%$ and $-6 \cdot 3 \%$, and $\delta^{18} \mathrm{O}$ between $-7 \cdot 4 \%$ and $-4 \cdot 8 \%$. In dolomites, $\delta^{13} \mathrm{C}$ values range from $-7 \cdot 7 \%$ to $-5 \cdot 1 \%$ and from $-7 \cdot 8 \%$ o to $-6 \cdot 1 \%$ for $\delta^{18} \mathrm{O}$. In samples containing both calcite and dolomite, the $\delta^{18} \mathrm{O}$ values in dolomite are lighter (average $0 \cdot 8 \%$ ) than those obtained in the same sample from calcite.

\section{INTERPRETATION OF THE DIAGENETIC SEQUENCE}

The different textures recognized, their arrangement and the geochemical data allow the interpretation of the sequence of diagenetic processes that formed these nodules (Fig. 8).

\section{Formation of anhydrite nodules}

The morphology of the nodules and the presence of anhydrite inclusions in the quartz and dolo-

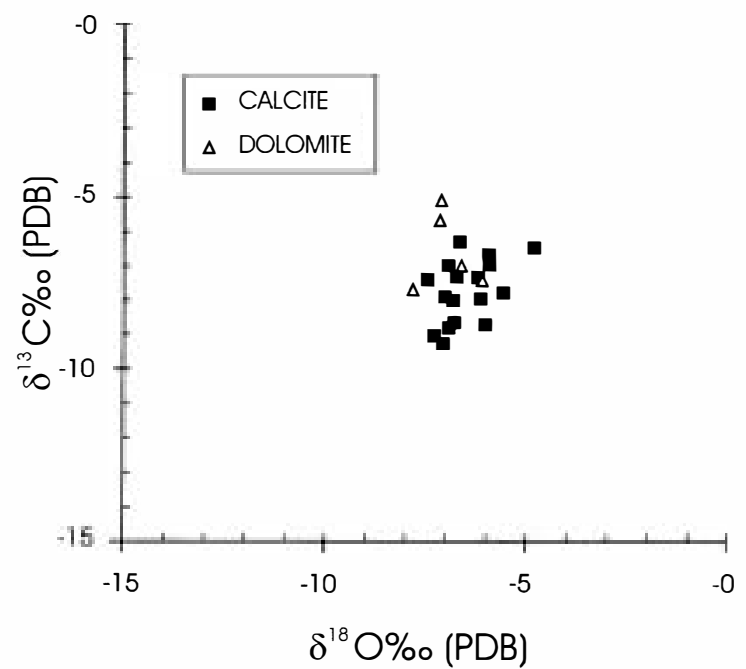

Fig. 7. Cross-plot of $\delta^{18} \mathrm{O}-\delta^{13} \mathrm{C}$ values of the calcite and dolomite of the cauliflower nodules. mite indicate that the nodules had an anhydrite precursor. In terrestrial settings, anhydrite nodules are found in playa-lake environments (Rodríguez-Aranda et al., 1991; Salvany et al., 1994), in pedogenic profiles such as gypcretes from the Miocene of Chile (Hartley \& May, 1998) or in palustrine evaporite settings such as in the Miocene Calatayud Basin in Spain (Sanz-Rubio et al., 1999). In these environments, anhydrite can precipitate directly within capillary saline solutions (Kinsman, 1974; Rodríguez-Aranda, 1995) in the presence of some organic compounds, which promotes anhydrite precipitation (Cody \& Hull, 1980). In the study case, the pedogenic cortex and the presence of organic structures (fungi) in the outer part of the nodules indicate that the nodules formed in a surficial vadose environment. The widespread distribution of the nodules in the basin, as demonstrated by the presence of similar nodules in the same bed over a distance of $>35 \mathrm{~km}$ (Bustillo et al., 1999), strongly indicates the presence of a single continuous water table.

\section{Formation of carbonate coatings}

The morphology and arrangement of the pores and laminations seen in these coatings are similar to structures formed by calcification of root structures and associated microorganisms (Mack \& James, 1992; Alonso-Zarza, 1999). The recrystallized fabric of the coatings and the lack of any relationship with the current water table indicate that they are not recent. These coatings probably formed by pedogenic processes at very nearly the same time as the anhydrite nodules.

\section{Silicification}

The presence of anhydrite inclusions concentrated in the outer parts of the nodules is the main argument for the nodules having formed by the replacement of an anhydrite precursor, which proceeded from the outside inwards. The presence of quartz mosaics with a considerable amount of scattered anhydrite inclusions may indicate a volume-for-volume replacement of anhydrite by silica in the initial stages. In a subsequent stage, the rate of anhydrite dissolution exceeded quartz precipitation, producing secondary porosity (Chowns \& Elkins, 1974). The increasing sulphate dissolution allowed growth of the quartz crystals in a less dense mass of sulphate and so favoured the organiza- 


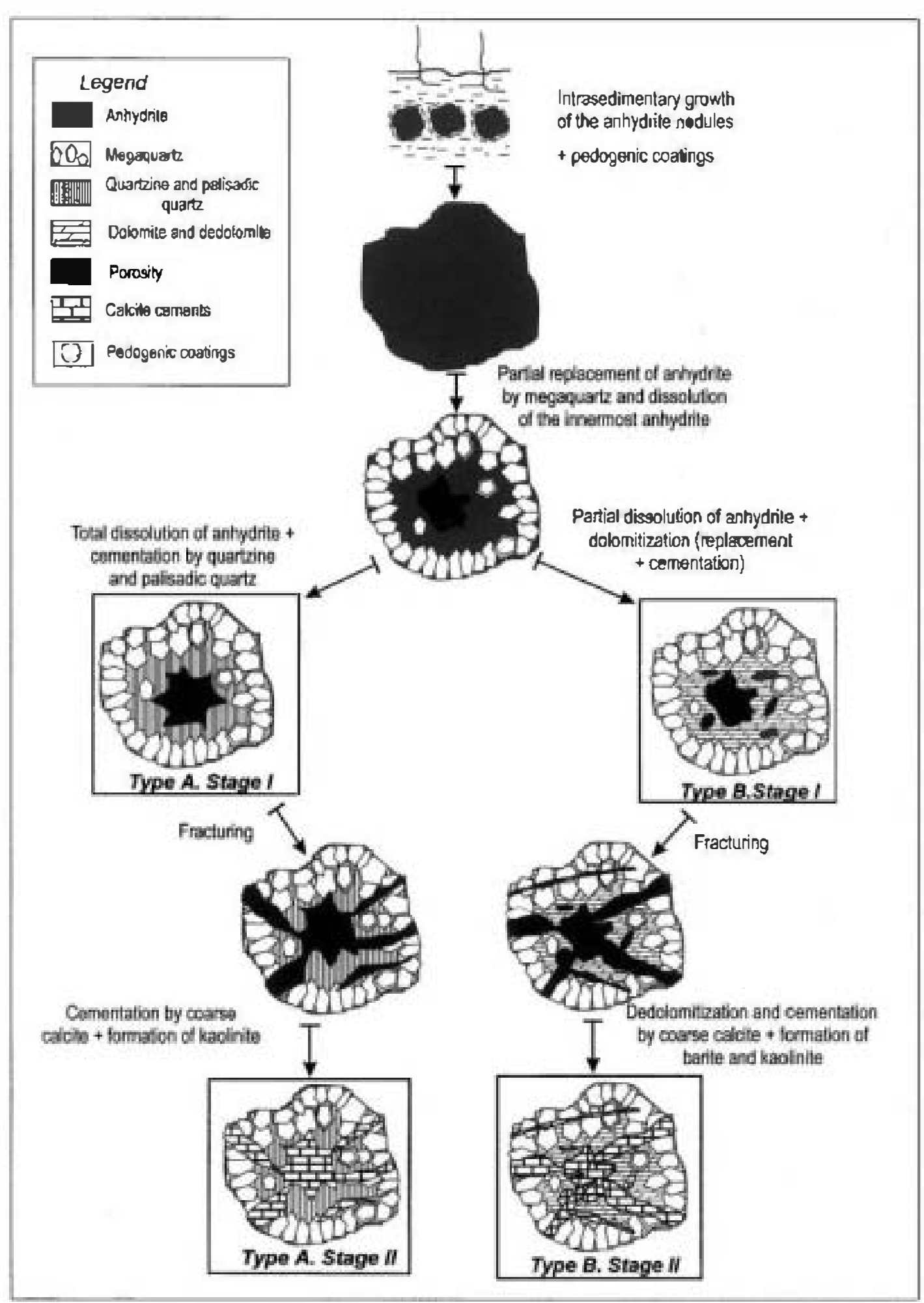

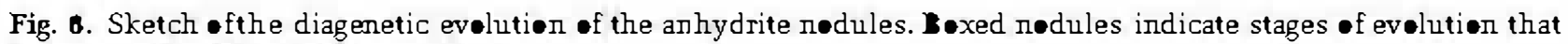
have been identified in the nodules.

tion of inclusions conforming to the euhedral shape of the growing quartz crystals (Tucker, 1976a).
After the initial replacement and dissolution of the anhydrite, two general diagenetic sequences can be recognized (Fig. 8). In type A nodules, the 
complete dissolution of anhydrite enabled the precipitation of quartz and calcite cements. Drusy quartz lacking anhydrite inclusions occurs in the innermost part of the nodules and represents the first clear quartz cement (Fig. 8, type A, stage I). Bands of quartzine constitute the last phase of quartz cementation. In type $B$ nodules, the process of silicification ends with the formation of megaquartz crystals with the remaining anhydrite replaced by dolomite (Fig. 8, type B, stage I).

The dissolution and replacement of anhydrite by quartz is indicative of the circulation of groundwaters supersaturated in silica and the low availability of sulphates (Tucker, 1976a). Folk \& Pittman (1971) and Siedlecka (1976) considered that high $\mathrm{pH}$ or sulphate-rich environments favoured the presence of megaquartz and quartzine. The silica concentration of the groundwater was controlled by the $\mathrm{pH}$. Under alkaline conditions, detrital quartz and other silicates of the red mudstones or adjacent red clastic deposits can be dissolved, increasing the silica concentration in the groundwater, and a slight decrease in $\mathrm{pH}$ enabled their precipitation. Fibrous quartz textures, present in the innermost part of some nodules, are indicative of precipitation from solutions with higher silica concentrations than the mosaics of megaquartz crystals (Milliken, 1979). Therefore, the sequence of quartz textures suggests precipitation from solutions with increasing silica concentration.

The replacement of anhydrite by quartz has been considered an early diagenetic process in shallow-marine and terrestrial environments (e.g. Tucker, 1976a,b; Geeslin \& Chafetz, 1982; Maliva, 1987, among others). Only exceptionally, and based on the presence of hydrocarbon inclusions in megaquartz, has silicification of anhydrite nodules been interpreted as a burial diagenetic process (Ulmer-Scholle et $\boldsymbol{a l . ,}$ 1993). In the present case, the presence of organic filaments on the surfaces of some euhedral crystals (Fig. 5F), similar to the fungal filaments described by Feldmann et al. (1997), suggests that silicification was an early diagenetic process that occurred with no significant burial.

\section{Dolomitization}

Dolomitization is very commonly associated with silicified anhydrite nodules. It can be earlier (Maliva, 1987), concomitant (García-Garmilla \& Elorza, 1996) or later than silicification (Friedman \& Shukla, 1980). In the present case, dolomite engulfs and corrodes the quartz crystals and fills cavities either within the quartz crystals or in the inner part of the nodules. All these features indicate that dolomitization occurred after silicification.

Three observations have to be considered when interpreting the dolomitization process: (i) there was no previous carbonate phase, and dolomitization occurred replacing anhydrite; (ii) bacterial bodies and organic filaments are present within the dolomite crystals; (iii) only the nodules in which the anhydrite was not totally leached contain dolomite. These observations suggest that dolomitization was driven by bacterial sulphate reduction of the remaining anhydrite or of sulphate ions present in the groundwaters. In this process, two moles of $2 \mathrm{HCO}_{3}{ }^{-}$are released for each mole of $\mathrm{SO}_{4}{ }^{2-}$ reduced (Berner, 1980; Wright, 1999). Sulphate reduction may promote dolomitization by: (a) removal of the dissolved $\mathrm{SO}_{4}{ }^{2-}$, which may act as an inhibitor of dolomitization; (b) production of alkalinity; and (c) production of $\mathrm{NH}_{4}{ }^{+}$, which may release adsorbed $\mathrm{Mg}^{2+}$ (Baker \& Kastner, 1981). Dolomitization by sulphate-reducing bacteria is currently a matter of discussion and may be more important than previously thought (Burns et al., 2000).

Although the $\delta^{13} \mathrm{C}$ values obtained for the dolomites formed through this process may vary from negative to strongly positive (Mazzullo, 2000), the isotopic composition of the nodules (Fig. 7) fits well with the wide range of values of organogenic dolomites formed by sulphate reduction. In our case, the negative $\delta^{13} \mathrm{C}$ values indicate an important contribution of ${ }^{12} \mathrm{C}$ from degraded organic matter. Morad et al. (1992) have suggested that the influence of carbon derived from soil organic matter may, among other causes, explain the low $\delta^{13} \mathrm{C}$ values of the dolomitic cements of the Buntsandstein sandstones. In addition, dolomite and calcite (either cement or dedolomite) show different isotopic values, indicating that their formation took place in waters of different composition. The lighter values of dolomite may suggest a more organic control of their formation than in the formation of calcite.

\section{Fracturing}

Some nodules contain fractures that affect all the quartz textures and the dolomite. However, the outer part of the nodule did not collapse (Fig. 8). Angular quartz fragments (breccias) formed as the result of the fracturing and are now cemented by 
calcite. Calcite cements precipitated in fractures could contribute to the enlargement of the fractures.

\section{Calcite spar cementation, dedolomitization, barite and kaolinite precipitation}

The close association of calcite cements, dedolomitization, kaolinite and barite suggests the input of relatively fresh, dilute and oxygenated waters of meteoric origin. Calcite, either cement or dedolomite, has light oxygen isotopic values (Fig. 7), which point to a meteoric origin. Dedolomitization accounts not only for the replacement of dolomite, but also for the dissolution of relic anhydrite in the dolomite. Dedolomitization of these iron-rich dolomites resulted in iron-poor calcite and the precipitation of iron oxyhydroxides parallel to the calcite crystal faces. Iron can accumulate in the boundaries between any quartz phase and late calcite cements or on the boundary between dolomite/dedolomite and the last calcite cement.

Barite is fairly common in quartz nodules and may also occur in association with celestite (Siedlecka, 1972). Celestite is absent in the nodules. Barite occurs only in nodules that contain dolomite or calcite after dolomite (Fig. 8), which suggests that sulphate came from the dissolution of the anhydrite inclusions of the dolomite. Barite solubility calculations demonstrate that changes in salinity cause variations in the barium sulphate activity coefficient (Monnin, 1999). Thus, a decrease in the salinity causes an increase in the activity coefficient and favours the precipitation of the barite. In the studied nodules, barite precipitation was favoured by the input of freshwaters. These freshwaters may also have carried different ions from the drainage of the uplands (Palaeozoic massif and Triassic sediments), which contained a variety of epithermal minerals including barite (Concha et al., 1992).

Kaolinite has hardly ever been reported in this type of nodule. Only Scholle et al. (1992) have described kaolinite 'booklets' within blocky calcite spar in calcite-replaced evaporite rosettes from the Delaware Basin. However, the association of barite and kaolinite is not rare in clastic deposits that have undergone early diagenesis under the influence of acidic, meteoric porewaters and the decay of organic matter (Diekmann \& Wopfner, 1996). Aluminium required for kaolinite precipitation could also come from the weathering of feldspars in the red mudstones, and the

\section{PALAEOENVIRONMENTAL CONTROLS ON THE OCCURRENCE OF CAULIFLOWER-LIKE NODULES}

The presence of the quartz cauliflower-like nodules has been used to infer data about the position of the coastline and also as evidence for a change from a transgressive to a regressive situation (Chown \& Elkins, 1974). Moreover, these nodules have been used to indicate relatively arid climates (Folk \& Pittman, 1971; Siedlecka, 1976; Tucker, 1976b). The detailed sedimentology carried out on the nodule bed, its position within the basin and its own characteristics provide some information about the climatic and tectonic conditions that prevailed during their formation.

\section{Climate}

The nodules are restricted to just one bed within the Sm unit. This unit represents the deposition of ephemeral and meandering fluvial systems under a semi-arid climate with marked seasonality (Muñoz et al., 1992; Sánchez-Moya et al., 1997). At this time, precipitation was sporadic and was followed by dry periods and subsequent evaporation. During evaporative periods, capillary rise of phreatic waters occurred through the highly permeable orange conglomerates and sandstones of unit S (Fig. 1). Thus, oversaturation of calcium sulphate occurred within the vadose zone. The nodule bed may indicate either more intense evaporative processes or longer, drier periods.

\section{Tectonism}

The cauliflower-like nodules are found over a wide area of the Triassic basin. The bed can be followed for more than $35 \mathrm{~km}$. Moreover, this bed, which was only examined in the cratonic area in the present study (Fig. 1), continues into the more subsiding areas of the basin. This suggests that the area was relatively flat, and tectonic activity was at a minimum. This would account for the stabilization of the groundwater table, leading to the basinwide distribution of these nodules at the same stratigraphic level. Thus, the presence of the cauliflower-like nodules reflects episodes of tectonic stability and low relief, related in time to the expansion of the 
Triassic basin. At this stage, the sedimentation area was wider and compartmentalization of the basin minimal. The occurrence of these beds in the sedimentary record may be used as a correlation tool in continental fluvial settings.

\section{CONCLUSIONS}

The Buntsandstein deposits of central Spain contain a red mudstone bed, in which quartz cauliflower nodules after anhydrite can be found throughout the fluvial basin. These nodules show complex patterns of replacement and cementation textures by mostly quartz and carbonates. The original anhydrite nodules probably formed during a period of evaporative concentration by capillary rise. The nodules formed within the vadose zone, occasionally under the influence of pedogenic processes. Soon after their formation, and under more dilute conditions possibly related to wetter periods, the anhydrite was partially replaced by megaquartz. This replacement took place under surficial conditions, as indicated by the presence of a number of fungal filaments on the quartz surface. From this point, their diagenetic evolution is more complex and dependent on the presence or absence of anhydrite. Nodules in which anhydrite dissolution was complete (type A) followed a simpler diagenetic path. Replacement by megaquartz was followed by quartz cementation (quartzine and palisadic quartz), fracturing and a late phase of calcite spar cementation occasionally containing kaolinite. Nodules in which anhydrite was not totally leached (type B) lack quartz cements and underwent dolomitization that was driven by sulphate reduction. Dedolomitization, calcite spar cementation and barite precipitation are the latest processes to affect these nodules.

As this bed is present across most of the Triassic basin, it may be used in correlation. These nodules offer information not only on their diagenetic history, but also on the climatic and tectonic conditions that resulted in their extensive formation across the fluvial basin.

\section{ACKNOWLEDGEMENTS}

This work was supported by project PB97-1208 of DGES and also by PB98-0668-C02-0. The authors wish to thank G. Herrero for his special care in making the thin sections. Members of the Petrology Department also contributed with suggestions on the identification of silicate minerals and textures. Robert Maliva, Dana Ulmer-Scholle and an anonymous reviewer improved the paper through their suggested revisions. Peter Mozley is thanked for his editorial work.

\section{REFERENCES}

Al-Aasm, I.S., Taylor, B.E. and South, B. (1990) Stable isøt॰pe analysis $\bullet$ multiple carbonate samples using selective acid extraction. Chem. Geol, 80, 119-125.

Alonse-Zarza, A.M. (1999) Initial stages of laminar calcrete formation by røots: examples frøm the Neøgene of central Spain. Sed. Geol., 126, 177-191.

Arbey, F. (1980) Les formes de la silice et l'identification des évaporites dans les formations silicifiées. Bull. Centres Rech. Explor.-Prod. Elf-Aquitaine, 4, 309-365.

Baker, P.A. and Kastner, M. (1981) Constraints on the formation of sedimentary dolømite. Nature, 213, 214-216.

Berner, R.A. (1980) Early Diagenesis - A Theoretical Approach. Princeton University Press, New Jersey, 241 pp.

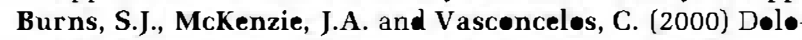
mite formation and biøgechemical cycles in the Phanerz•ic. Sedimentoløgy, 47 (Suppl. 1), 49-61.

Bustille, M.A., García-Guinea, J., Martínez-Frías, J. and Delgad•, A. (1999) Unusual sedimentary geodes filled by goldbearing hematite laths. Geol. Mag., 136, 671-679.

Chowns, T.M. and Elkins, J.E. (1974) The origin of quartz geodes and cauliflewer cherts through the silicification of anhydrite nodules. J. Sed. Petrol, 44, 885-903.

Cødy, R.D. and Hull, A.B. (1980) Experimental growth of primary anhydrite at løw temperatures and water salinities. Geology, 8, 505-509.

Concha, A., Oyarzun, R., Lunar, R., Sierra, J., Doblas, M. and Lillø, J. (1992) The Hiendelaencina epithermal silver-base metal district, Central Spain: tectenic and mineralizing processes. Mineral. Deposita, 27, 83-89.

Diekmann, B. and Wøpfner, H. (1996) Petregraphic and diagenetic signatures of climatic change in peri- and postglacial Kar»• Sediments of SW Tanzania. Palaengengr. Palaeoclimatel. Palaeøecol, 125, 5-25.

Diemer, J.A. and Bridge, J.S. (1988) Transition from alluvial plain t॰ tide-deminated ceastal depesits assøciated with the Tournaisian marine transgression in SW Ireland. In: TideInfluenced Sedimentary Environments and Facies. Sedimentology and Petroleum Geology (Eds P.L. de Bøer, A. van Gelder and S.D. Ni॰), pp. 359-388. Reidel Publishing, Dordrecht.

Elørza, J. and Rødríguez-Lázar•, J. (1984) Late Cretaceøus quartz geodes after anhydrite frøm Burgos, Spain. Geøl. Mag., 121, 107-113.

Feldmann, M., Neher, J., Jung, W. and Graf, F. (1997) Fungal quartz weathering and iron crystallite formation in an Alpine envirøment, Piz Alv, Switzerland. Eclogae Geel. Helv., 90, 541-556.

F•lk, R.L. and Pitmnan, J.S. (1971) Length-slow chalcedony: a new testament for vanished evaporites. J. Sed. Petrol., 41, 1045-1058.

Friedman, G.M. and Shukla, V. (1980) Significance of authigenic quartz euhedra after sulphates: example from the 
